\title{
Problematika Program Studi Pendidikan Bahasa Mandarin di Universitas Negeri di Indonesia
}

\author{
Maria Mintowati \\ Universitas Negeri Surabaya \\ mintowati@unesa.ac.id
}

\begin{abstract}
Abstrak
Eksistensi Program Studi Pendidikan Bahasa Mandarin di universitas negeri di Indonesia telah ditorehkan sejak 2009 hingga saat ini. Dalam perjalanannya yang masih relatif singkat, terdapat sejumlah tantangan, yakni penyediaan dosen, bahan ajar, kualitas lulusan, akreditasi, dan kerja sama antarprodi, antaruniversitas dengan universitas serta lembaga dalam dan luar negeri. Solusi yang dilakukan guna menghadapi berbagai tantangan tersebut adalah melalui Asosiasi Program Studi Bahasa Mandarin Indonesia (APSMI) yang telah didirikan pada 2015. Melalui APSMI sejumlah Prodi PBM dari PTN dan PTS berdiskusi dan telah merumuskan (1) Profil Lulusan selaras dengan level 7 KKNI, (2) Capaian Pembelajaran Lulusan, (3) kerja sama, (4) penyelenggaraan workshop dan seminar baik nasional maupun internasional. Langkah berikutnya adalah Prodi PBM berturut serta dalam program-program yang dilontarkan oleh Dikti, yakni (1) Akreditasi, (2) Permata dan Transfer Kredit, dan (3) penyiapan pembukaan Prodi PPG untuk lulusan S-1 Prodi PBM. Status akreditasi Prodi PBM mayoritas masih bernilai C, karena belum terpenuhinya kecukupan dosen tetap PNS (di PTN penerimaan CPNS dan PNS sangat bergantung pada Pemerintah RI) dan pada saat visitasi belum ada lulusan. Program transfer kredit sudah diprogram dan direalisasikan Belmawa Dikti pada semester genap 2017/2018, sedangkan Prodi PPG masih dalam wacana.
\end{abstract}

Kata kunci: problematika, program studi, Pendidikan Bahasa Mandarin, Indonesia

\begin{abstract}
The existence of the Mandarin Education Study Program at state universities in Indonesia has been inscribed since 2009 until today. In a relatively short journey, there are a number of challenges, namely the provision of lecturers, teaching materials, graduate quality, accreditation, and interpersonal cooperation, universities with universities as well as institutions within and outside the country. The solution to deal with these challenges is through the Association of Indonesian Language Studies Program (APSMI) which has been established in 2015. Through APSMI a number of PBM Study Programs from PTN and PTS discuss and formulate (1) Graduates' profiles are aligned with level 7 KKNI, 2) Graduate Learning Achievement, (3) cooperation, (4) organizing workshop and seminar both national and international. The next step is the successive PBM Study Program as well as in the programs directed by Dikti, namely (1) Accreditation, (2) Gems and Transfer of Credit, and (3) preparation of PPG Prodi for graduates of S-1 Prodi PBM. Most of the accreditation status of PBM Prodi is still worth $C$, because the insufficiency of permanent lecturers of civil servant (in PTN acceptance CPNS and PNS highly dependent on RI Government) and at the time of visitasi not yet there are graduates. Credit transfer program has been programmed and realized Belmawa Dikti in the even semester of 2017/2018, while Prodi PPG is still in the discourse.
\end{abstract}

Keywords: problematic, study program, Mandarin Education, Indonesia 


\section{A. Pendahuluan}

Program Studi Pendidikan Bahasa Mandarin (Prodi PBM) di Perguruan Tinggi Negeri Indonesa telah berdiri sejak 2009. Pendirian prodi ini dilaksanakan berdasarkan usulan perguruan tinggi yang bersangkutan atau pemberian mandat oleh Direktur Jenderal Pendidikan Tinggi. Dalam Mintowati (2015) disampaikan bahwa secara berturut-turut, Prodi PBM dibuka di lima PTN, yakni di Universitas Tanjung Pura, Pontianak (2009), Universitas Negeri Surabaya, Surabaya (2010), Universitas Negeri Malang, Malang (2011), Universitas Negeri Semarang, Semarang (2011), dan Universitas Negeri Jakarta, Jakarta (2014) (Mintowati, 2016:111).

Dalam perjalanannya, Prodi Pendidikan Bahasa Mandarin di lima PTN tersebut, tentu saja mengalami berbagai masalah, baik ketersediaan pendidik, bahan ajar, maupun hal-hal lain yang diperlukan untuk pengoperasinalan sebuah prodi baru. Kedua hal yang disebutkan penulis hingga saat ini masih tetap merupakan persoalan inti yang belum tuntas diselesaikan. Hal-hal lain yang juga perlu perintisan dan pengembangan Prodi PBM adalah penyusunan kurikulum berbasis Kerangka Kualifikasi Nasional Indonesia (KKNI) guna merumuskan profil lulusan, capaian pembelajaran, akreditasi program studi, penguatan asosiasi prodi, kerja sama, keterlibatan prodi dalam program-program yang ditawarkan Kementerian Riset, Teknologi, dan Pendidikan Tinggi, utamanya Program Pertukaran Mahasiswa Tanah Air Nusantara (Permata) dan transfer kredit, serta Program Pendidikan Profesi (PPG) untuk guru-guru mata pelajaran Bahasa Mandarin (PPG dalam jabatan) dan alumni Prodi PBM (PPG Prajabatan), utamanya tentang pendirian dan pembukaan Prodi PPG bagi alumni Prodi PBM dan guru mata pelajaran Bahasa Mandarin. Berbagai tantangan tersebut tentu saja harus dihadapi bersama guna ditemukan solusinya.

Berdasarkan latar belakang tersebut, dalam makalah ini dibahas (1) profil lulusan berdasarkan KKNI, (2) capaian pembelajaran, (3) konversi mata kuliah untuk Program Permata dan Transfer Kredit, (4) akreditasi prodi, (5) penggalangan kerja sama dalam dan luar negeri, (6) penguatan asosiasi, dan (7) Program Studi Pendidikan Profesi Guru (Prodi PPG) bagi guru dalam jabatan dan prajabatan mata pelajaran Bahasa Mandarin. Diharapkan melalui pembahasan tersebut dapat ditemukan solusinya guna perbaikan dan peningkatan kualitas penyelenggaraan Prodi PBM di Indonesia. 


\section{B. Pembahasan}

\section{Profil Lulusan Berdasarkan KKNI}

Dalam Permenristekdikti Republik Indonesia Nomor 44 Tahun 2015 tentang Standar Nasional Pendidikan Tinggi (SN Dikti) dimuat tentang (1) standar kompetensi lulusan, (2) standar isi pembelajaran, (3) standar proses pembelajaran, (4) standar penilaian pembelajaran, (5)standar dosen dan tenaga kependidikan, (6) standar sarana dan prasarana pembelajaran, (7) standar pengelolaan pembelajaran, dan (8) standar pembiayaan pembelajaran. Kedelapan standar tersebut saling mendukung dan saling terkait. Dari delapan standar tersebut, yang sangat gayut dengan perumusan profil lulusan berdasarkan KKNI adalah standar kompetensi lulusan (SKL). Yang dimaksud dengan standar kompetensi lulusan adalah kriteria minimal tentang kualifikasi kemampuan lulusan yang mencakup sikap, pengetahuan, dan keterampilan. Ketiga cakupan tersebut disuratkan dalam rumusan capaian pembelajaran $(\mathrm{CP})$ lulusan.

SKL merupakan acuan utama pengembangan tujuh standar lainnya, yakni standar isi pembelajaran, standar proses pembelajaran, standar penilaian pembelajaran, standar dosen dan tenaga kependidikan, standar sarana dan prasarana pembelajaran, standar pengelolaan pembelajaran, dan standar pembiayaan pembelajaran. SKL dimaksudkan agar lulusan memiliki capaian pembelajaran. Misalnya, lulusan Prodi Strata-1 (S-1) memiliki capaian pembelajaran level 7 berdasarkan KKNI. Lebih lanjut, disuratkan dalam Undang-undang Nomor 12 Tahun 2012 tentang Pendidikan Tinggi, utamanya dalam pasal 29 bahwa KKNI merupakan acuan pokok dalam penetapan kompetensi lulusan, baik untuk pendidikan akademik, pendidikan vokasi, maupun pendidikan profesi. Mengingat kedudukan dan fungsi SKL yang sangat strategis dan penting tersebut, perumusan SKL bersifat wajib bagi sebuah prodi.

Profil lulusan Prodi PBM di Indonesia telah dibahas dalam Musyawarah Nasional I (Munas I) Asosiasi Program Studi Mandarin Indonesia (APSMI). Munas I diseleggarakan di Universitas Brawijaya Malang dan berlangsung pada 27--29 Mei 2016. Dalam Munas I tersebut, dihasilkan draf Kurikulum Prodi PBM oleh sembilan perguruan tinggi penyelenggara Prodi PBM. Kesembilan perguruan tinggi tersebut adalah Universitas Negeri 
Surabaya (Surabaya), Universitas Negeri Jakarta (Jakarta), Universitas Negeri Malang (Malang), Universitas Negeri Semarang (Semarang), Universitas Kristen Indonesia (Jakarta), Universitas Widya Kartika (Surabaya), Universitas Universal (Batam(, Universitas Ma Chung (Malang), dan Universitas Tanjung Pura (Pontianak). Yang dibahas dalam Munas I adalah penetapan profil lulusan Prodi PBM, capaian pembelajaran, dan butir-butirnya. Adapun beban SKS dan pembetukan mata kuliah diserahkan kepada Prdi PBM masing-masing perguruan tinggi. Hasil pembahasa telah dibahas dalam sidang pleno Munas I dan telah diserahkan kepada Ketua Panitia Pelaksana Munas I dan Ketua Umum APSMI. Namun, karena berbagai hal, draf tersebut belum disahkan sebagai keputusan Munas I dan belum diserahkan kepada Dirjen Pembelajaran dan Kemahasiswaan Dikti (Belmawa).

Dalam Munas II APSMI yang diselenggarakan di Universitas Kristen Petra Surabaya da Universitas Negeri Surabaya pada 13--15 Juli 2017, kembali dilakukan pembahasan draf Kurikulum Prodi PBM. Pembahasan difokuskan pada pematangan rumusan profil lulusan dan capaian pembelajaran beserta butir-butirya. Pembahasan dilakukan oleh Ketua Prodi PBM atau yang mewakili dari delapan perguruan tinggi penyelenggara Prodi PBM. Kedelapan perguruan tinggi tersebut adalah Universitas Negeri Surabaya, Universitas Negeri Jakarta, Universitas Negeri Malang, Universitas Negeri Semarang, Universitas Widya Kartika, Universitas Universal, dan Universitas Ma Chung. Hasil pembahasan dikuatkan dengan ditandatanganinya Berita Acara oleh seluruh Kaprodi PBM di Indonesia dan akan ditindaklanjuti oleh Ketua Umum APSMI untuk diaudiensikan ke Dirjen Belmawa. Berikut ini hasil rumusan profil lulusan Prodi PBM pada Munas I dan II APSMI.

Tabel 1: Rumusan Profil Lulusan Prodi Pendidikan Bahasa Mandarin di Indonesia

\begin{tabular}{|l|l|}
\hline Profil Lulusan Prodi PBM (Munas I) & Profil Lulusan Prodi PBM (Munas II) \\
\hline $\begin{array}{l}\text { 1. Pendidik bahasa Mandarin } \\
\text { 2. Peneliti pemula bidang pendidikan } \\
\text { bahasa Mandarin }\end{array}$ & $\begin{array}{l}\text { 1. Pendidik bahasa Mandarin } \\
\text { 2. Peneliti pemula bidang pendidikan bahasa } \\
\text { Mandarin }\end{array}$ \\
$\begin{array}{l}\text { 3. Tenaga terampil dan atau wirausaha } \\
\text { dalam bidang yang berkaitan dengan } \\
\text { bahasa Mandarin }\end{array}$ & $\begin{array}{l}\text { 3. Tenaga terampil dan atau wirausaha dalam } \\
\text { bidang yang berkaitan dengan pendidikan } \\
\text { bahasa Mandarin }\end{array}$ \\
\hline
\end{tabular}
Sumber: Laporan Divisi Prodi PBM Munas I APSMI (2016) dan Munas II APSMI (2017)

Dalam tabel 1 tersebut, tampak perubahan rumusan profil lulusan Prodi PBM, utamanya pada butir 3. Perubahan tersebut pada klausa "dalam bidang yang berkaitan dengan bahasa 
Mandarin" menjadi "dalam bidang yang berkaitan dengan pendidikan bahasa Mandarin". Hal ini dilakukan berdasarkan alasan logis, yakni agar lulusan Prdi PBM tidak mengambil “kapling” lulusan Prodi Bahasa Mandarin atau Prodi Sastra Mandarin dan sejenisnya.

Yang lebih penting lagi adalah butir (1) profil lulusan S-1 Prodi PBM, yakni pendidik Bahasa Mandarin. Secara jelas, maksudnya adalah lulusan S-1 Prodi PBM adalah menjadi pendidik untuk mata pelajaran Bahasa Mandarin. Gelar yang disandang lulusan prodi ini adalah Sarjana Pendidikan (S.Pd.). Hal ini jelas sangat relevan dengan visi dan misi Prodi PBM. Berikutnya, butir kedua profil lulusan Prodi PBM adalah peneliti pemula bidang pendidikan bahasa Mandarin. Sebagaimana dipahami, calon guru dan guru mata pelajaran Bahasa Mandarin diharapkan bukan hanya menjadi pendidik mata pelajaran Bahasa Mandarin, tetapi juga mampu meneliti masalah-masalah yang gayut dengan pembelajaran bahasa Mandarin. Dalam hal ini, mereka diharapkan bukan hanya sekali meneliti untuk keperluan penyusunan skripsi sebagai salah satu persyaratan meraih gelar S.Pd. Mereka juga diharapkan menjadi peneliti pemula untuk masalah pembelajaran bahasa Mandarin, misalnya melakukan penelitian eksperime, korelasi, tindakan kelas, juga penelitian pengembangan. Melalui penelitian di bidang pembelajaran bahasa Mandarin, dapat ditingkatkan kualitas pembelajaran dan juga kompetensi profesi para guru.

Guna meraih peluang lapangan kerja yang lebih luas bagi lulusan Prodi PBM dirumuskanlah butir ketiga, yakni tenaga terampil dan atau wirausaha dalam bidang yang berkaitan dengan pendidikan bahasa Mandarin. Dalam butir ketiga ini terkandung maksud bahwa lulusan Prodi PBM diharapkan dapat menciptakan peluang kerja mandiri yang masih dalam ruang lingkup pendidikan bahasa Mandarin. Sebagai contoh, lulusan Prodi PBM dapat membuka kursus belajar bahasa Mandarin, menjadi penulis bahan ajar bahasa Mandarin, berwirausaha memproduksi media pembelajaran bahasa Mandarin, dan lain-lain. Untuk itu, mahasiswa Prodi PBM juga dibekali keterampilan berkarya melalui mata kuliah Kewirausahaan.

\section{Capaian Pembelajaran Lulusan}

Sebagaimana telah disampaikan pada Pembahasan Butir 1, SKL dinyatakan dalam capaian pembelajaran lulusan (CPL). CPL mencakup sikap, pengetahuan, dan keterampilan yang memenuhi kriteria minimal kualifikasi kemampuan lulusan. Sikap dan keterampilan umum ditetapkan dalam Lampiran Permenristekdikti Nomor 44 Tahun 2015, karena itu tidak ditampilkan dalam makalah ini untuk menghemat halaman. Pengetahuan dan keterampilan 
khusus disusun oleh (1) Forum program program studi sejenis atau nama lain yang setara atau (2) pengelola program studi dal hal tidak memiliki forum program studi sejenis untuk diusulkan kepada dan ditetapkan oleh menteri. Terjadi perubahan materi SN Dikti dalam kedua permen tersebut. Adapun ketentuan peralihan tentang rumusan pengetahuan dan keterampilan khusus LPL dalam Permendikbud Nomor 49 Tahun 2014 (pasal 64) dan Permenristekdikti Nomor 44 Tahun 2015 (pasal 66) disajikan tabel 2 berikut ini.

Tabel 2: Ketentuan Peralihan Rumusan Pengetahuan da Keterampilan Khusus

\begin{tabular}{|c|c|}
\hline $\begin{array}{l}\text { Permendikbud Nomor 49 Tahun } 2014 \\
\text { (pasal 64) }\end{array}$ & $\begin{array}{c}\text { Permenristekdikti Nomor } 44 \text { Tahun } 2015 \\
\text { (pasal 66) }\end{array}$ \\
\hline $\begin{array}{l}\text { Rumusan pengetahuan dan keterampilan } \\
\text { khusus sebagaimana dimaksud dalam } \\
\text { pasal } 7 \text { ayat (3) yang belum dikaji dan } \\
\text { ditetapkan oleh Direktorat Jenderal } \\
\text { Pendidikan Tinggi, perguruan tinggi } \\
\text { dapat menggunakan rumusan yang } \\
\text { disusun secara mandiri untuk proses } \\
\text { penjaminan mutu internal di perguruan } \\
\text { tinggi dan proses penjaminan mutu } \\
\text { eksternal melalui akreditasi. }\end{array}$ & $\begin{array}{l}\text { Rumusan pengetahuan dan keterampilan } \\
\text { khusus sebagaimana dimaksud dalam pasal } 7 \\
\text { ayat (3) yang belum dikaji dan ditetapkan oleh } \\
\text { Menteri, perguruan tinggi dapat menggunakan } \\
\text { rumusan yang disusun secara mandiri untuk } \\
\text { proses penjaminan mutu internal di perguruan } \\
\text { tinggi dan proses penjaminan mutu eksternal } \\
\text { melalui akreditasi. }\end{array}$ \\
\hline
\end{tabular}

Sumber: Gunawan dan Waluyo (2016)

Berdasarkan hasil Munas I APSMI pada 27--29 Mei 2016 di Universitas Brawijaya Malang, rumusan CPL Prodi PBM, khususnya rumusan CPL Pengetahuan dan Keterampilan Khusus disajikan secara ringkas berikut ini.

CPL untuk Pengetahuan mencakup bidang linguistik, pedagogi, penelitian, dan kewirausahaan. Bidang linguistik difokuskan pada pengetahuan tentang cabang-cabang disiplin dalam mikrolinguistik plus pengetahuan tentang Sinologi mengingat belajar bahasa akan tidak sempurna jika tidak belajar budaya penutur asli bahasa yang sedang dipelajari. Mengingat Prodi Pendidikan, mahasiswa dibekali dengan ilmu tentang belajar dan mengajar dan ilmu-ilmu yang bersangkut paut dengan pembelajaran. Guna mendalamikedua cakupan aspek pengetahuan tersebut, mahasiswa juga dibekali dengan Metodologi Penelitian Pendidikan.Mata kuliah ini khas bagi Prodi Pendidikan. Selanjutnya, guna menghadapi 
tantangan hidup, mahasiswa juga dibekali dengan kewirausahaan. Maksudnya adalah lulusan Prodi Pendidikan Bahasa Mandarin tidak harus mengandalkan pekerjaan sebagai pegawai negeri sipil. Mereka diharapkan mampu menciptakan lapangan pekerjaan sendiri, misalnya dengan membuka kursus bahasa Mandarin (Laporan Divisi Prodi PBM dalam Munas I APSMI (2016).

Uraian rumusan CPL tentang keterampilan khusus erat kaitannya dengan rumusan CPL tentang pengetahuan. Yang membedakan adalah pada pengetahuan, pumpunan materi pada ilmu tentang linguistik, pedagogi, penelitian, dan kewirausahaan. Selanjutnya, pengetahuan tentang hal-hal tersebut diwujudkan sebagai keterampilan.Artinya, mahasiswa mampu menerapkan secara terampil keempat konsep tersebut dalam pembelajaran dan penelitian serta dalam berwira usaha (Laporan Divisi Prodi PBM dalam Munas I APSMI, 2016).

Rumusan CPL tersebut, pada Munas II APSMI yang diselenggarakan oleh Universitas Negeri Surabaya dan Universitas Kristen Petra Surabaya pada 13--15 Juli 2017, direvisi menjadi sebagai berikut.

Tabel 3: Rumusan CPL: Pengetahuan

\begin{tabular}{|l|l|}
\hline $\begin{array}{l}\text { 1.Kebahasaan } \\
\text { dan Sinologi }\end{array}$ & $\begin{array}{l}\text { 1. Menguasai konsep teoretis tentang ilmu bahasa Mandarin } \\
\text { (Fonologi, Morfologi, Sintaksis, dan Semantik). }\end{array}$ \\
$\begin{array}{l}\text { 2. Menguasai pengetahuan tentang Negara Tiongkok secara umum } \\
\text { (sejarah, geografi, dan budaya), serta memiliki pemahaman lintas } \\
\text { budaya. }\end{array}$ \\
\hline 2. Pedagogi & $\begin{array}{l}\text { Menguasai konsep teoretis ilmu pedagogi. } \\
\text { pembelajaran, strategi belajar mengajar, media pembelajaran, } \\
\text { penilaian pembelajaran, dan psikologi pendidikan). }\end{array}$ \\
\hline 3. Penelitian & Menguasai konsep metodologi penelitian. \\
\hline 4. Kewirausahaan & $\begin{array}{l}\text { Menguasai konsep kewirausahaan yang berkaitan dengan bahasa } \\
\text { Mandarin }\end{array}$ \\
\hline
\end{tabular}

Sumber: Laporan Divisi Prodi PBM dalam Munas II APSMI (2017)

Tabel 4: Rumusan CPL: Keterampilan khusus

\section{Kebahasaan dan Sinologi}

1. Mampu mengaplikasikan keterampilan berbahasa Mandarin (Menyimak, Berbicara, Membaca, Menulis) baik lisan maupun tulis setara HSK 4 dan HSKK Menengah.

2. Mampu memanfaatkan pengetahuan tentang Negara Tiongkok secara umum (sejarah, geografi, dan budaya), serta memiliki 
pemahaman lintas budaya dalam praktik berbahasa Mandarin dan pembelajaran bahasa Mandarin.

2. Pedagogi Mampu memanfaatkan pengetahuan pedagogi untuk merancang, melaksanakan, dan mengevaluasi pembelajaran bahasa Mandarin.

Mampu memanfaatkan pengetahuan metodologi penelitian untuk

3. Penelitian merancang, melaksanakan, dan melaporkan hasil penelitian bahasa, sastra, budaya (dalam konteks pembelajaran bahasa Mandarin), dan pembelajaran bahasa Mandarin.

Mampu memanfaatkan IPTEKS dan keterampilan berbahasa

4. Kewirausahaan Mandarin untuk mewujudkan tenaga terampil dan wirausahawan yang berkaitan dengan pendidikan bahasa Mandarin.

Sumber: Laporan Divisi Prodi PBM dalam Munas II APSMI (2017)

Tabel 5: Rumusan CPL Pengetahuan dan Keterampilan Khusus Prodi PBM di Indonesia

\begin{tabular}{|c|c|}
\hline Ranah & Butir-butir Kompetensi Lulusan \\
\hline \multirow[t]{11}{*}{ Pengetahuan } & $\begin{array}{l}\text { a. Menguasai konsep teoretis tentang fonologi bahasa Mandarin } \\
\text { (struktur tata bunyi bahasa Mandarin, bunyi inisial, final, ton, } \\
\text { perubahan ton, intonasi, dan aturan penulisan Hanyu Pinyin) }\end{array}$ \\
\hline & $\begin{array}{l}\text { b. Menguasai konsep teoretis tentang morfologi bahasa Mandarin } \\
\text { (proses morfologis, jenis proses morfologis, jenis morfem, dan kelas } \\
\text { kata) }\end{array}$ \\
\hline & $\begin{array}{l}\text { c. Menguasai konsep teoretis tentang sintaksis bahasa Mandarin } \\
\text { (hakikat sintaksis, alat dan satuan sintaksis, analisis fungsi kalimat, } \\
\text { jenis kalimat tunggal, jenis kalimat majemuk, bentuk kalimat khas } \\
\text { bahasa Mandarin) }\end{array}$ \\
\hline & $\begin{array}{l}\text { d. Menguasai konsep teoretis tentang semantik bahasa Mandarin } \\
\text { (hakikat semantik, jenis makna, relasi makna, perubahan makna) }\end{array}$ \\
\hline & e. Menguasai pengetahuan tentang sejarah Tiongkok \\
\hline & f. Menguasai pengetahuan tentang geografi Tiongkok \\
\hline & $\begin{array}{l}\text { g. Menguasai pengetahuan tentang budaya Tiongkok dalam konteks } \\
\text { pemahaman lintas budaya (Indonesia-Tiongkok) }\end{array}$ \\
\hline & h. Menguasai konsep teoretis tentang perencanaan pembelajaran. \\
\hline & i. Menguasai konsep teoretis tentang strategi belajar mengajar \\
\hline & j. Menguasai konsep teoretis tentang media pembelajaran \\
\hline & k. Menguasai konsep teoretis tentang penilaian pembelajaran \\
\hline
\end{tabular}




\begin{tabular}{|c|c|}
\hline & 1. Menguasai konsep teoretis tentang psikologi pendidikan \\
\hline & m. Menguasai hakikat penelitian dan fungsi penelitian \\
\hline & n. Menguasai jenis-jenis penelitian \\
\hline & o. Menguasai konsep metode penelitian \\
\hline $\begin{array}{l}\text { Keterampilan } \\
\text { Khusus }\end{array}$ & $\begin{array}{l}\text { a. Mampu mengaplikasikan keterampilan menyimak bahasa } \\
\text { Mandarin baik lisan dan/atau tulis setara HSK } 4 \text {. }\end{array}$ \\
\hline & $\begin{array}{l}\text { b. Mampu mengaplikasikan keterampilan berbicara bahasa } \\
\text { Mandarin baik lisan dan/atau tulis setara HSKK Menengah. }\end{array}$ \\
\hline & $\begin{array}{l}\text { c. Mampu mengaplikasikan keterampilan membaca } \text { bahasa } \\
\text { Mandarin baik lisan dan/atau tulis setara HSK } 4 \text {. }\end{array}$ \\
\hline & $\begin{array}{l}\text { d. Mampu mengaplikasikan keterampilan menulis bahasa Mandarin } \\
\text { baik lisan dan/atau tulis setara HSK } 4 \text {. }\end{array}$ \\
\hline & $\begin{array}{l}\text { e. Mampu memanfaatkan pengetahuan ilmu bahasa Mandarin dalam } \\
\text { praktik berbahasa Mandarin. }\end{array}$ \\
\hline & $\begin{array}{l}\text { f. Mampu memanfaatkan pengetahuan ilmu bahasa Mandarin dalam } \\
\text { pembelajaran bahasa Mandarin. }\end{array}$ \\
\hline & $\begin{array}{l}\text { g. Mampu memanfaatkan pengetahuan pedagogi untuk merancang } \\
\text { pembelajaran bahasa Mandarin (Rencana Pelaksanaan } \\
\text { Pembelajaran/RPP). }\end{array}$ \\
\hline & $\begin{array}{l}\text { h. Mampu memanfaatkan pengetahuan pedagogi } \text { untuk } \\
\text { melaksanakan pembelajaran bahasa Mandarin } \\
\text { Rencana Pelaksanaan Pembelajaran/RPP). }\end{array}$ \\
\hline & $\begin{array}{l}\text { i. Mampu memanfaatkan pengetahuan pedagogi untuk menilai } \\
\text { pembelajaran bahasa Mandarin (sesuai dengan Rencana } \\
\text { Pelaksanaan Pembelajaran/RPP). }\end{array}$ \\
\hline & $\begin{array}{l}\text { j. Mampu memanfaatkan pengetahuan metodologi penelitian } \\
\text { untuk merancang penelitian bahasa, sastra, budaya (dalam konteks } \\
\text { pembelajaran bahasa Mandarin), dan pembelajaran bahasa } \\
\text { Mandarin. }\end{array}$ \\
\hline & $\begin{array}{l}\text { k. Mampu memanfaatkan pengetahuan metodologi penelitian } \\
\text { untuk melaksanakan penelitianbahasa, sastra, budaya, dan } \\
\text { pembelajaran bahasa Mandarin. }\end{array}$ \\
\hline & $\begin{array}{l}\text { 1. Mampu memanfaatkan pengetahuan metodologi penelitian untuk } \\
\text { melaporkan hasil penelitian bahasa, sastra, budaya, dan } \\
\text { pembelajaran bahasa Mandarin }\end{array}$ \\
\hline & $\begin{array}{l}\text { m. Mampu memanfaatkan IPTEKS dan keterampilan berbahasa } \\
\text { Mandarin untuk mewujudkan tenaga terampil yang berkaitan }\end{array}$ \\
\hline
\end{tabular}


dengan bahasa Mandarin.

n. Mampu memanfaatkan IPTEKS dan keterampilan berbahasa Mandarin untuk mewujudkan wirausahawan yang berkaitan dengan bahasa Mandarin.

Sumber: Laporan Divisi Prodi PBM dalam Munas II APSMI (2017)

Revisi hasil pembahasan CPL Prodi PBM di Indonesia pada Munas APSMI I dan II terjadi pada rumusan CPL Pengetahuan dan Keterampilan Khusus pada butir 1 dari "Kebahasaan" menjadi "Kebahasaan dan Sinologi". Revisi berikutnya terdapat pada CPL 4. Keterampilan Khusus butir b yang berbunyi, "Mampu mengaplikasikan keterampilan berbicara bahasa Mandarin baik lisan dan/atau tulis setara HSKK Menengah.” Dalam tabel-tabel yang telah disajikan, butir-butir yang direvisi dicetak miring.

\section{Konversi Mata Kuliah untuk Program Permata dan Transfer Kredit}

Salah satu program yang ditawarkan oleh Direktorat Pembelajaran dan Kemahasiswaan Dikti adalah Program Permata dan Transfer Kredit. Program ini dimulai pada 2014 (Pedoman Permata Dikti, 2016). Pada 2017, LPTK yang terdaftar sebagai penyeleggara Program Permata dan Transfer Kredit adalah Universitas Negeri Semarang, Universitas Negeri Surabaya, Universitas Negeri Yogyakarta, Universitas Negeri Jakarta, Universitas Negeri Malang, Universitas Negeri Makassar, Universitas Negeri Gorontalo, Universitas Negeri Padang, Universitas Negeri Medan, Universitas Negeri Manado, Universitas Pendidikan Ganesha, dan Universitas Pendidikan Indonesia. Dari kedua belas LPTK tersebut, yang memiliki Prodi PBM adalah Universitas Negeri Surabaya, Universitas Negeri Semarang, Universitas Negeri Jakarta, dan Universitas Negeri Malang.

Universitas Negeri Surabaya (Unesa) pada 2017 mengirimkan sebanyak 45 rang dari 7 fakultas. Khusus dari Fakultas Bahasa dan Seni, dikirimkan sebanyak 6 orang. Dari keenam orang mahasiswa tersebut, satu orang mahasiswa berasal dari Prodi PBM FBS Unesa, yakni Avi Novi Yanti (NIM 15020774015). Pengiriman mahasiswa Prodi PBM ini merupakan kali pertama. Namun, berdasarkan informasi dari Dikti, mahasiswa tersebut menyampaikan bahwa masih terdapat kendala dalam penyesuaian mata kuliah dan jumlah SKS. Oleh karena itu, program Permata dan Transfer Kredit diundur pelaksanaannya pada Semester Genap 2017/2018. Pada Semester Gasal 2017/2018, mahasiswa tersebut tetap berkuliah di Prodi PBM FBS Unesa. 


\section{Akreditasi Program Studi}

Dalam Undang-undang Nomor 12 Tahun 2012 tentang Pendidikan Tinggi, pasal 53 ayat 2 dinyatakan bahwa sistem penjaminan mutu untuk pendidikan tinggi terdiri atas (1) sistem penjaminan mutu internal (SPMI) dan (2) sistem penjaminan mutu eksternal (SPME). SPMI dikembangkan oleh perguruan tinggi, sedangkan SPME dilakukan melalui akreditasi.

Untuk akreditasi prodi diatur dalam pasal 33 ayat (3) dan (5) UU Dikti bahwa prodi diselenggarakan atas izin Menteri setelah memeuhi persyaratan minimum akreditasi dan prodi mendapatkan akreditasi pada saat memeroleh izin penyelenggaraan. Adapun tujuan akreditasi diatur dalam pasal 55 ayat (1) dan (2) UU Dikti.

Akreditasi Prodi PBM di LPTK Negeri masih berada pada nilai C (4 LPTK) dan nilai B (1 LPTK) (ban-pt.kemendiknas.go.id/direktori.php). Kendala yang dihadapi Prodi PBM di LPTK negeri pada saat akreditasi dilaksanakan adalah belum terpenuhinya dosen tetap (enam orang) dan belum dihasilkannya lulusan pada 2014. Guna mengatasi kedua kendala tersebut, LPTK melakukan peng-homebase-an dosen dari prodi sejenis di fakultas dan perekrutan dosen (pada 2017; hampir selama tiga tahun tidak ada seleksi penerimaan CPNS) dan menghasilkan lulusan. Hal penting yang dilakukan Prodi PBM FBS Unesa adalah melakukan percepatan akreditasi pada Maret 2017. Setelah divisitasi, hasil akreditasi Prodi PBM FBS Unesa adalah B (berlaku sejak September 2017-September 2022).

\section{Kerja Sama}

Kerja sama merupakan satu upaya perguruan tinggi untuk meningkatkan kualitas. Kerja sama antaruniversitas melibatkan universitas satu dengan universitas lainnya, dituangkan dalam Memorandum of Understanding (MoU). Pada 2008 dan 2009, Universitas Negeri Surabaya telah menandatangai MoU dengan Central China Normal University (CCNU), Wuhan. MoU tersebut merupakan salah penunjang yang sangat penting bagi berdirinya Prodi PBM FBS Unesa (2010). Salah satu tindak lanjut MoU tersebut adalah diselenggarakannya Seminar Internasional oleh Unesa (2009) tentang pembelajaran bahasa Mandarin. Selanjutnya, CCNU pada 2009--2010 mengirimkan dua orang tenaga pendidik guna memperlancar persiapan dan penyelenggaraan Prodi PBM di Unesa.

Langkah berikutnya, Unesa dan Hanban atau Confucius Institute Headquarters sebagai institusi publik yang berafilisasi dengan Kementerian Pendidikan China, pada 2011 telah 
mendirikan Pusat Bahasa Mandarin (孔子学院) di Unesa. Dalam perannya, Pusat Bahasa Mandarin sangat mendukung penyelenggaraan pembelajaran Prodi PBM, terutama dengan penugasan para penutur asli untuk mengajar. Dalam tiap tahun, ada 4--6 orang penutur asli yang mengajar. Selain itu, Pusat Bahasa Mandarin juga menyumbangkan buku-buku berbahasa Mandarin, mendukung penyelenggaraan Seminar Nasional Mandarin (sejak 2011) hingga saat ini dalam bentuk dana dan pembicara kunci. Pada 24 Juli 2017, Unesa dan NTOU juga telah menandatangai Mou.

Kerja sama melalui APSMI juga terjalin antara seluruh anggota APSMI dengan beberapa universitas dan asosiasi di luar negeri. Sebagai contoh, Mou-Mou yang telah dijalin adalah sebagai berikut.

Tabel 6: Daftar Kerja Sama APSMI

\begin{tabular}{|l|l|l|}
\hline No. & \multicolumn{1}{|c|}{ MoU } & Tanggal Mou \\
\hline 1. & $\begin{array}{l}\text { The Indonesian Assosiaciation of Mandarin Studies Program with } \\
\text { The Assosiaciation of Teaching Chinese as Second Language } \\
\text { Taiwan }\end{array}$ & 24 Juli 2017 \\
\hline 2. & $\begin{array}{l}\text { The Indonesian Assosiaciation of Mandarin Studies Program with } \\
\text { Chinese Language Center Taiwan National Ocean University }\end{array}$ & 24 Juli 2017 \\
\hline 3. & $\begin{array}{l}\text { The Indonesian Assosiaciation of Mandarin Studies Program with } \\
\text { World Chinese Language Association Taiwan }\end{array}$ & 24 Juli 2017 \\
\hline 4. & $\begin{array}{l}\text { The Indonesian Assosiaciation of Mandarin Studies Program with } \\
\text { Departement of Teaching Chinese as Second Language, Chung } \\
\text { Yuan Christian University }\end{array}$ & 28 Juli 2017 \\
\hline
\end{tabular}

\section{Sumber: Sekretariat APSMI (2017)}

\section{Penguatan Asosiasi}

Beberapa universitas negeri dan swasta di Indonesia telah mendirikan dan mengoperasionalkan prodi-prodi Mandarin, baik yang berbasis kependidikan maupun murni atau non-kependidikan. Kemudian, pada 2009--2014, ada lima LPTK yang membuka Prodi PBM. Hal ini terjadi seiring dengan kemajuan pesat yang dicapai oleh China, baik dalam bidang ekonomi, perdagangan, maupun industri. Dengan makin kuatnya pengaruh negara China terhadap berbagai bidang kehidupan, banyak negara di dunia, termasuk Indonesia menjalin kerja sama dengan China. Karena itu, sangat dipandang perlu memelajari bahasa dan budaya China. 
Pada beberapa universitas, Prodi Sastra China atau prodi-prodi yang berfokus pada bahasa Mandarin dan pendidikan bahasa Mandarin, para ketua program studi (Kaprodi) sangat memandang perlu didirikannya asosiasi prodi bahasa Mandarin. Karena itu, pada 10--11 April 2015, ada empat belas prodi berkongres di Bandung. Dari Kongres I tersebut lahirlah sebuah asosiasi, yakni Asosiasi Program Studi Bahasa Mandarin Indonesia (APSMI). APSMI merupakan asosiasi yang mencakupi tiga prodi, yakni (1) S-1 Prodi Pendidikan Bahasa Mandarin; (2) S-1 Prodi Bahasa/Sastra China; (3) D-3 Prodi Bahasa/Sastra China. Dalam tulisa ini tidak dibedakan penyebutan "China", "Tionghoa", "Tiongkok", "Mandarin", dan lain-lain. Penggunaan kata "Mandarin" mengacu pada istilah yang ada dalam nama mata pelajaran "Bahasa Mandarin" dan nama kurikulum, khususnya silabus mata pelajaran Bahasa Mandarin yang secara resmi digunakan oleh Kementerian Pendidikan dan Kebudayaan Republik Indonesia. Bergabungnya ketiga macam prodi tersebut didasari oleh masih terbatasnya jumlah prodi masing-masing. Pengurus APSMI terdiri atas dewan penasihat, ketua, sekretaris, bendahara, ketua divisi Prodi S-1 PBM, ketua divisi Prodi S-1 Bahasa/Sastra Mandarin, ketua divisi Prodi D-3 Bahasa/Sastra Mandarin, serta ketua pengembangan penelitian, pembelajaran, dan pengabdian kepada masayarakat, humas, dan koordinator wilayah. Kepengurusan berlaku sampai dengan tiga tahun (SK Pengurus APSMI Nomor 1 Tahun 2015, 12 April 2015).

Akta Pendirian APSMI telah disahkan notaris. APSMI juga telah memiliki Anggaran Dasar dan Anggaran Rumah Tangga (AD dan ART). Setiap tahun diselenggarakan musyawarah nasional. Sejak berdiri pada 11 April 2016, APSMI telah menyelenggarakan Munas I APSMI (Malang, 2016) dan Munas II APSMI (Surabaya, 2017). Hasil Munas I yang ditindaklanjuti dalam Munas II adalah Kurikulum Prodi Mandarin (Prodi S-1 PBM, Prodi S-1 Bahasa/Sastra Mandari, Prodi D-3 Bahasa/Sastra Mandarin, dan Prodi D-4 Bahasa/Sastra Mandarin). Pada 13--15 Desember 2016 juga telah berlangsung seminar internasional yang diselenggarakan di Universitas Universal Batam. Kemudian, dalam Munas II APMI telah dilaksanakan juga seminar nasional dan workshop penulisan karya ilmiah bagi peserta Munas (13--14 Juli 2017. Pada 22--30 Juli 2017, pengurus dan anggota APSMI telah melakukan workshop di National Taiwan Ocean University (NTOU) di Keelung City. Dalam pelaksanaan workshop tersebut, peran TETO (Taipei Economic and Traide Office) sangat besar guna menjembatani ASPMI dan NTOU. 


\section{Pendidikan Profesi Guru (PPG)}

Dalam Undang-undang Nomor 12 Tahun 2012 tentang Pendidikan Tinggi disampaikan bahwa pendidikan profesi merupakan pendidikan tinggi setelah program sarjana. Artinya, lulusan S-1 Prodi Kependidikan dari LPTK dan D-4 non-kependidikan yang berbakat dan berminat sebagai pendidik hendaknya menjalani pendidikan profesi selama satu tahun. Pendidikan profesi tersebut dimaksudkan sebagai persyaratan keahlian khusus sebagaimana profesi dokter, dan sebagainya.

Pendidikan profesi dilaksanakan sesuai dengan bunyi pasal 8 Undang-undang Nomor 14 Tahun 2004 tentang Guru dan Dosen. Dalam pasal tersebut dinyatakan bahwa guru wajib memunyai kualifikasi akademik, kompetensi, sertifikat pendidik, sehat jasmani dan rohani, dan kemampuan mewujudkan tujuan pendidikan nasional. Berikutnya, dalam pasal 8 ayat (1) disampaikan bahwa sertifikat pendidik diperoleh melalui Program PPG. Ketentuan lain yang mendasari pelaksanaan PPG adalah Peraturan Pemerintah Nomor 74 Tahun 2008 tentang Guru merupakan dasar penyiapan guru sebagai pendidik profesional.

Dalam Pannen dkk. (2017) disampaikan bahwa pelaksana Program PPG adalah LPTK dengan acuan Standar Pendidikan Guru (Dikgu). Guna persiapan penyelenggaraan Program PPG, Kemenristek Dikti, utamanya Belmawa menerbitkan Pedoman Pelenggaraan Pendidikan Profesi Guru (2017). Disampaikan dalam buku tersebut bahwa Program PPG diselenggarakan dalam bentuk Program Studi PPG. Secara garis besar, dalam pedoman tersebut dibahas (1) rasionalisasi dan landasan hukum penyelenggaraan PPG sebagai program studi; (2) penyelenggara Prodi PPG; (3) Seleksi Calon Mahasiswa PPG (bersubsidi dan berswadana); (4) kurikulum dan sistem pembelajaran; (5) sistem pembayaran; (6) penjaminan mutu.

Unesa sebagai salah satu LPTK telah menjadi penyelenggara PPG sejak 2012 (untuk peserta SM-3T tahun 2011) hingga saat ini (2017, untuk peserta SM-3T 2016), mulai dari Angkatan I--V. Peserta PPG dalam lima angkatan tersebut adalah lulusan S-1 Kependidikan yang telah menjalani Program Sarjana Mendidik di daerah Terpencil, Terluar, dan Tertinggal (SM-3T) selama satu tahun. SM-3T yang diselenggarakan tersebut diberi nama PPG SM-3T di bawah payung Program Maju Bersama Mencerdaskan Indonesia (MBMI). Program PPG SM-3T tersebut diikuti oleh peserta dari 13 Prodi, yakni PGPAUD, PGSD, BK, Pendidikan Biologi, Pendidikan Matematika, Pendidiksn Sejarah, PPKN, Pendidikan Bahasa dan Sastra 
Indonesia, Pendidikan Pendidikan Bahasa Inggris, Pendidikan Bahasa Jerman, Pendidikan Bahasa Jepang, PendidikanJasmani dan Kesehatan, serta Pendidikan Ekonomi (Nurlaela, 2013). Berdasarkan informasi tersebut, PPG SM-3T untuk lulusan S-1 Pendidikan Bahasa Mandarin tidak termasuk di dalamnya. Hal ini demikian, karena belum ada peluang bagi lulusan S-1 Prodi PBM sebagai peserta Program SM-3T. Dengan demikian, ke depan, Unesa diharapkan dapat membuka Prodi PPG untuk lulusan S-1 Prodi PBM.

Perlu disampaikan dalam tulisan ini, Prodi PBM Unesa telah berperan aktif untuk meningkatkan kualitas guru dan mata pelajaran Bahasa Mandarin melalui Program Pendidikan dan Latihan Profesi Guru sejak 2013 hingga saat ini (2017). Melalui program tersebut, peserta yang lulus berhak memperoleh sertifikat pendidik dan tunjangan profesi.

\section{Simpulan}

Berdasarkan pembahasan yang telah dilakukan, dapat disimpulkan bahwa terdapat sejumlah tantangan, yakni penyediaan dosen, bahan ajar, kualitas lulusan, akreditasi, dan kerja sama antarprodi, antaruniversitas dengan universitas serta lembaga dalam dan luar negeri. Solusi yang dilakukan guna menghadapi berbagai tantangan tersebut adalah melalui Asosiasi Program Studi Bahasa Mandarin Indonesia (APSMI) yang telah didirikan pada 2015. Melalui APSMI sejumlah Prodi PBM dari PTN dan PTS berdiskusi dan telah merumuskan (1) Profil Lulusan selaras dengan level 7 KKNI, (2) Capaian Pembelajaran Lulusan, (3) kerja sama, (4) penyelenggaraan workshop dan seminar baik nasional maupun internasional. Langkah berikutnya adalah Prodi PBM berturut serta dalam program-program yang dilontarkan oleh Dikti, yakni (1) Akreditasi, (2) Permata dan Transfer Kredit, dan (3) penyiapan pembukaan Prodi PPG untuk lulusan S-1 Prodi PBM. Status akreditasi Prodi PBM mayoritas masih bernilai C, karena belum terpenuhinya kecukupan dosen tetap PNS dan pada saat visitasi belum ada lulusan. Program transfer kredit sudah diprogram dan direalisasikan Belmawa Dikti pada semester genap 2017/2018, sedangkan Prodi PPG masih dalam wacana. 


\section{Daftar Rujukan}

ban-pt.kemendiknas.go.id/direktori.php. Direktori SK Hasil Akreditasi Pogram Studi.

Direktorat Jenderal Pembelajaran dan Kemahasiswaan Dikti. 2016. Pedoman Program Pertukaran Mahasiswa Tanah Air Nusantara (Permata). Jakarta.

Gunawan, J. dan Beradette M. Waluyo. 2016. "Sosialisasi Standar Nasional Pendidikan Tinggi”. Jakarta.

Laporan Divisi Prodi PBM dalam Munas I APSMI. 2016. Malang.

Laporan Divisi Prodi PBM dalam Munas II APSMI. 2017. Surabaya.

Mintowati. 2015. "Peningkatan Kualitas Program Studi (Pendidikan) Bahasa Mandarin". Makalah disajikan dalam Forum Fakultas Bahasa dan Seni Indonesia. Bukittinggi, 27--29 September 2015.

Nurlaela, Lutfiyah. 2013. "Pendidikan Profesi Guru, Jalan Menuju Guru Profesional" dalam Kompasiana. 12 Juni.

Pannen, Paulina dkk. 2017. Pedoman Pelenggaraan Pendidikan Profesi Guru. Jakarta: Dirjen Pembelajaran dan Kemahasiswaan. Dirjen Kelembagaan (ILTDIKTI). Dirjen Pendidikan Guru.

Peraturan Pemerintah Nomor 74 Tahun 2008 tentang Guru

Permenristekdikti RI Nomor 44 Tahun 2015 tentang Standar Nasional Pendidikan Tinggi (SN Dikti). Jakarta.

SK Pengurus APSMI Nomor 1 Tahun 2015, 12 April 2015, Periode 2015--2018. Jakarta.

Tim Pengembang SPMI Kemeristek Dikti. 2016. "Standar Nasial Pendidikan Tinggi. Jakarta: Dirjen Pembelajaran dan Kemahasiswaan. Direktorat Penjaminan Mutu.

Undang-undang Nomor 14 Tahun 2004 tentang Guru dan Dosen.

Undang-undang Nomor 12 Tahun 2012 tentang Pendidikan Tinggi.

\section{Data Penulis}

Nama

: Dr. Maria Mintowati, M.Pd.

Program studi

: Pendidikan Bahasa Mandarin

Jurusan

: Bahasa dan Sastra Mandarin

Perguruan Tinggi

: Universitas Negeri Surabaya

Hp

: +6281357127015

Email

: mintowati@unesa.ac.id 